\title{
Tackling COVID-19 with Nanotechnology
}

\author{
Imran Moin* \\ Imran Moin, Nano Biotech Lab, Kirori Mal College, University of Delhi, India
}

\section{EDITORIAL}

A new virus familiar yet very strange has griped almost all the countries of the world. It has spread its tentacles griping the richand poor alike. It does not discriminate between class, religion, race or gender. About four months have elapsed since it was first identified in the Wuhan [1,2] province of China and yet it spreads with an unimagined pace and an unabat9ed ferocity. It has been named as severe acute respiratory syndrome coronavirus 2 (SARS. CoV-2) [1], coronaviruses belong to the family Coronaviridae, with protein coat and positive-sense single-stranded RNA genome, among the RNA viruses they are one of the largest ones in genome size. They infect both mammals and birds. The medical fraternity is still in doubt about its origin and cure. It has struck one of the most powerful nations of the world and rendered it helpless. People are left in utter confusion and various conspiracies theories - from attributing the origin of virus to labs to a desperate attempt by some nations to wage a biological war against the other - are making rounds on social media. A brief discussion below would better help understand the mechanism of virus multiplication and spread from one species to another.

When virus infects its host it incorporates its genome into the genome of the host and hijacks the infected cells to carry out its function, for instance, the protein which forms coat of the coronavirus is synthesized in the endoplasmic reticulum of the infected cell. The virus is able to replicate itself inside the infected cell creating many copies of itself and release of these viruses takes place when the infected cell dies leading to infection of other healthy cells. These viruses during their replication acquire mutations (as replication machinery is slightly error prone) and novel viruses evolve in the environment due to mutation. Out of the recently evolved viruses only some are able to survive of the viruses which acquired the mutation, as mutation does not confer them any edge but a few are able to gain an advantage as it happened in the case of this novel coronavirus, it is claimed that SARS-CoV-2 originated in bats [3] but was able to infect humans also. Hence, Darwin's 'descent with modification' along with 'natural selection' explains the arrival of new species, in this case a virus and the other most prominent example is MDR microorganisms.
The present crisis triggered by the onslaught of this virus has bared many truths and proved many scientific theories correct even after decades of their formulation. It has proved the relevance of the words of Darwin and Malthus even today when humanity is believed to have conquered other planets.

The expansion of this virus and mounting number of deaths everyday has left the nations high and dry. In these desperate times many unfortunate incidents of violence and uncontrolled propagation of fake news is also on the rise and further compounding the problem. While it has wrecked one of best medical care system of the world, it has triggered a series of speculation about the havoc it would bring upon the nations which are poor and ill-equipped to handle this crisis. The cure or any vaccination effective enough to contain it seems a far-fetched idea at present. In these extraordinary times nanotechnology can make a significant contribution in this war against COVID-19, various nano-materials (like gold nanoparticles) are being utilized for rapid testing of the virus, nanofibre reusable masks are being manufactured to cope up with the increased demand[4]. Nano-bio interactions can be modified to completely understand the process of infection of a cell by SARS CoV-2. In conclusion, nanomedicines have been the focus of many researchers' and many of them are being studied for clinical trials.

The only precaution at present is social distancing and maintaining hygiene to control the exponential spread of this virus till the time some breakthrough in its treatment is achieved. We as human beings are still very vulnerable no matter the advancement in medical facilities and remarkable scientific feats. The world should never sit complacent as to its achievements for the impending crisis may sneak up on them from any unsuspected sources.

\section{REFERENCES}

1. Li Q, Guan X, Wu P, Wang X, Zhou L, Tong Y, et al. Early transmission dynamics in Wuhan, China, of novel coronavirus-infected pneumonia. New England Journal of Medicine. 2020.

2. Lu R, Zhao X, Li J, Niu P, Yang B, Wu H, et al. Genomic characterisation and epidemiology of 2019 novel coronavirus: implications for virus origins and receptor binding. The Lancet. 2020;395(10224):565-574.

3. Chan WC. Nano Research for COVID-19. ACS Nano. 2020.

"Correspondence to: Imran Moin, Nano Biotech Lab, Kirori Mal College, University of Delhi, India; Tel: +91-779-206-9804; E-mail: imoin@zoology. du.ac.in

Received: Apr 25, 2020; Accepted: Apr 28, 2020; Published: Apr 30, 2020

Citation: Moin I (2020) Tackling COVID-19 with Nanotechnology. J Nanomed Nanotech. 10:e534. doi: 10.35248/2157-7439.20.11.e534

Copyright: (C2019 Moin I. This is an open-access article distributed under the terms of the Creative Commons Attribution License, which permits unrestricted use, distribution, and reproduction in any medium, provided the original author and source are credited. 